ОСОБЛИВОСТІ ПРОЯВІВ РЕЗИСТЕНТНОСТІ ТА РИЗИКУ НАРКОТИЗАЦІЇ В ПІДЛІТКІВ І ЮНАКІВ

\title{
PARTICULARITIES OF MANIFESTATION OF RESISTANCE AND RISK OF DRUG ADDICTING AMONG TEENAGERS AND ADOLESCENTS
}

УДК 159.938

DOI https://doi.org/10.32843/2663-

5208.2020.14.18

\section{Кіреєва 3.0.}

д.психол.н.,

професор кафедри загальної психології

і психології розвитку особистості

Одеський національний університет

імені І.І. Мечникова

Харченко Н.М.

практичний психолог

Комунальний заклад

«Одеський педагогічний коледж» у статmі зазначено, що у підлітковому періоді та періоді юнацтва причини наркотизації є різними й численними. Проведено емпіричне вивчення особливостей особистостей різного віку, що мають ризик наркотизації (група ризику / група уваги) або $\epsilon$ резистентними до їх вживання. Встановлено дві групи у підлітків: перша - без ризику наркотизації, упевнені, цілеспрямовані, друга група тих, хто допускають вживання наркотичних речовин 3 імовірністю психічного зриву. Показано, на рівні статистичної значущості розбіжності між групами за наступними змінними: «Обізнаність», «Владний - лідируючий», «Незалежний-домінуючий», «Прямолінійний - агресивний», «Недовірливий - скептичний», «Відповідальний - великодушний», «Локус контролю-життя». Встановлено дві групі юнаків: перша з ризиком наркотизації при усвідомленому сенсі життя, знаннях та оточенні і друга - усвідомлені сенсом життя, з пов'язаними минулим, теперішнім і майбутнім. Показано на рівні статистичної значущості розбіжності між групами юнаків за такими змінними: «Обізнаність», «Прямолінійний агресивний», «Співпрацюючий - конвенційний», «Відповідальний - великодушний». Порівняно групи уваги / групи ризику у підлітків і юнаків. Зазначено, що юнаки групи уваги не визнають критику, переоцінюють власні можливості, можуть бути недовірливими до оточення за одночасної реалістичності суджень, володіють більш глибокими знаннями про наркотичні речовини, способи їх застосування, мають більшу вираженість ризику наркотизації, $є$ більш цілеспрямованими, життя сприймають як емоційно насичене і наповнене сенсом, уявляють себе як сильну особистість, що має свободу вибору, їм властиве почуття відповідальності і вони в міру доброзичливі. Порівняння груп юнаків і підлітків, що не мають ризику наркотизації, показало, що юнаки мають більше знань про наркотичні речовини та вони є більш скромними, можуть брати на себе обов'язки інших. Ключові слова: наркотизачія, особистість, підлітки, юнаки, резистентність.
The article states that there are numerous different causes of drug addiction during teenage and adolescence periods. An empirical study of the characteristics of different age individuals who have a risk of drug addicting (risk group / attention group) or who are resistant to its consumption was conducted. There are two groups of teenagers: a group - without the risk of drug addicting, they are confident, purposeful and a group of those who admit the consumption of drugs with the likelihood of mental breakdown. The differences between groups at the level of statistical significance on the following variables is shown: "Awareness", "Powerful - leading", "Independent-dominant", "Rectilinear - aggressive", "Distrustful - sceptical", "Responsible - generous", "Locus of control - life". There are two groups of adolescents who are at risk of drug addicting: a group which has conscious meaning of life, knowledge and environment, and a group who are aware of the meaning of life, present related to the past, and future. The differences between groups of adolescents at the level of statistical significance on the following variables is shown: "Awareness", "Rectilinear - aggressive", "Collaborator - conventional", "Responsible - generous". The attention groups / risk groups among teenagers and adolescents were compared. It is noted that young people in the attention group do not accept criticism, overestimate their own capabilities, may be distrustful of the environment with realistic judgments, have a deeper knowledge of drugs, its consumption, have a greater risk of drug addicting, are more focused, perceive life as emotional and full of meaning, imagine themselves as a strong person with freedom of choice, they have a sense of responsibility and they are moderately friendly. The comparison of groups of teenagers and adolescents who were not at risk of drug use showed that adolescents have more knowledge about drugs and were more modest and could take on the responsibilities of others.

Key words: drug addicting, personality, teenagers, adolescents, resistance.
Постановка проблеми. Наркотична залежність стала проблемою молодого покоління, що ускладнює їі соціальні наслідки. Формування наркотичної залежності у підлітків і юнаків займає особливе місце в сучасних дослідженнях в психології, медицині, педагогіці та соціології. В умовах сучасного розвитку суспільства, зростання бідності та соціальної нерівності, обмеженості можливості для розвитку, високої доступності ПАР, постійному створенні нових наркотиків необхідно краще розуміння факторів, які стимулюють і перешкоджають підліткам їх вживання.
Постановка завдання. Метою статті є розгляд особливостей проявів резистентності та ризику наркотизації в підлітків і юнаків.

Виклад основного матеріалу дослідження. Дослідження наркотичної залежності, іï розвитку, факторів виникнення проводяться в рамках психоаналітичного, біхевіористичного, гуманістичного, інтеракционістського, діяльнісного підходів, онтопсихології, теорії стресу і копінгу та інших. Так, згідно з біхевіористською теорією виникнення залежності споживання ПАР має тимчасовий підкріплюючий ефект у випадках стану стресу, 
нервового напруження, відсутності гарного настрою, надмірної втоми, особистого горя і болю. В психоаналізі вважається, що людина, яка вживає наркотики, має властивість знижувати тривогу. Гуманістичний напрям розглядає особистісний сенс наркотизації, який полягає в доступі до психологічних ресурсів, що полегшує міжособистісну комунікацію, самоактуалізацію, вивільнення творчої енергії особистості [3]. 3 погляду онтопсихології за наркоманією завжди криються розлади «Я», особистісна незрілість, відчуття провини (А. Менегетті). В логотерапії В. Франкла причина наркозалежності пов'язана з відчуттям втрати сенсу, а Е. Фромм розглядав вживання наркотиків як своєрідний протест проти соціального насильства і нудьги.

У сучасній науці ризик наркотизації особистості розглядають з позиції взаємодії сукупності біогенетичних, соціально-середовищних і індивідуально-психологічних передумов. Зазвичай підлітковий період пов'язують з початком вживання наркотичних речовин, оскільки цьому періоду дорослішання властиві специфічні (психофізіологічні, психологічні, соціально-психологічні) особливості, що породжують характерні типи девіантної поведінки при впливі невизначених, неоднозначних і суперечливих соціально-економічних умов. Особливе місце в психофізіологічних особливостях надається розвитку мозку, особливо тих областей, які пов'язані із зрілістю, самоконтролем і ухваленням рішень. Відомо, що зміни у взаємодії кори мозку та підкоркових структур з підвищеною активністю останніх призводять до підвищеної збудливості, емоційної лабільності, слабкості гальмівних процесів, гіперактивності. У зв'язку з послабленням контрольних функцій фронтальних відділів кори мозку страждає вся система довільної регуляції психічної діяльності та поведінки, це частково пояснює різноманітність підліткової ризикованої й імпульсивної поведінки і дії. 3 іншого боку, активність гормональних процесів впливає на нестійкість емоційної сфери підлітків, яка характеризується силою, змінюваністю, підвищеною чутливістю. Експерименти підлітків з наркотиками приводять до негайного задоволення, що примушує шукати його неодноразово. 3 моменту вживання наркотичних речовин підліток створює не тільки велику вірогідність розвитку повноцінної наркоманії в ранньому віці, але і збільшує ймовірність наркоманії в пізнішому віці. У юнаків ситуація обтяжується тим, що вони виступають транслятором наркотичної субкультури і полегшеного відношення до наркотиків. Ця субкультура пропонує такі цінності: наркотики бувають «серйозні» і «легкі»; наркотики роблять людину «вільною» і допомагають вирішувати життєві проблеми.
Стадії наркотизації описані О.В. Змановською [2], яка продемонструвала, що на першій стадії відбувається епізодичне вживання, що супроводжується позитивними емоціями з одночасним збереженням контролю. Далі ейфорійна дія наркотичної речовини значно зменшується, а іноді повністю зникає, формується індивідуальний ритм вживання за зберігання контролю. Ця стадія називається стадією психологічної залежності, коли відбувається короткочасне поліпшення психофізичного стану, але поступово відбувається звикання, і посилюються дезадаптивні стереотипи поведінки. На наступній стадії очевидні фізична залежність, втрата контролю, соціальна дезадаптація. Формується синдром залежності, який визначається як поєднання фізіологічних, поведінковихі когнітивних явищ, за яких вживання речовини або класу ПАР починає займати перше місце в системі цінностей індивідуума. Основною характеристикою синдрому залежності $€$ потреба (іноді непереборна) прийняти психоактивну речовину. У залежних від наркотиків відзначається високий рівень мотивації уникнення неуспіху, переважання страху перед неуспіхом над надією на успіх і такі спотворення мотиваційно-потребової сфери, як блокування часової перспективи і блокування потреби в захищеності, самоповазі, приналежності до референтної групи (В.Д. Менделевич). За даними як закордонних, так і вітчизняних дослідників, в осіб, що зловживають наркотиками, відзначається наявність когнітивного дефіциту, що проявляється в погіршенні показників пам'яті, уваги, асоціативного мислення.

Згідно з аналізом джерел наукової літератури причини наркотизації можуть бути різними і численними. До них належать: хімічна структура психоактивних речовин, їх фармакодинамічні і фармакокінетичні особливості, з якими пов'язаний його вплив на системи нейрохімії мозку і відповідні рецептори; легка доступність ПАР і значне розширення асортименту наркотиків; міра готовності суб'єкта до впливу наркотичних речовин, особливості розвитку людини; проживання в дисфункційних родинах; травма; наявність «привертаючих особистісних дефіцитів», до яких належать труднощі в диференціації виразів і регуляції емоцій, низька самооцінка, слаборозвинені навички міжособистісної комунікації, здатність протидіяти соціальному впливу та адекватно відповісти на нього; наявність психопатій і акцентуацій характеру істероїдного та епілептоїдного типу (А. Лічко), що зумовлено силою потягів, які властиві епілептоїдам; наявність певної установки стосовно можливості вживання тієї або іншої психоактивної речовини, яка формується до початку вживання в процесі соціалізації індивіда і визначає надалі 
його поведінку та інші. Жодна з перерахованих причин не може вважатися єдиною і повністю відповідальною за наркотизацію [1]. Навпроти чинників ризику зазвичай розташовують протективні чинники - чинники резистентності, до яких відносять для підлітків: міцні та позитивні сімейні зв'язки; батьківський нагляд та моніторинг діяльності дітей; чіткі правила поведінки, які послідовно виконуються в сім'ї; важливість надання підліткам точної, достовірної та оновленої інформації про ПАР, формування твердого переконання підлітків не вживати наркотиків (згідно з теорією самоефективності), зміцнення їх життєвих навичок для досягання життєвих цілей; невживання наркотиків серед родичів та близького оточення, профілактичні засоби у школі та інше [8].

Останнім часом набуває поширення погляд, що нахил до залежності криється в окремих «слабких ланках» особистісної структури (М.М. Іванец), які сурогатним способом заповнюють патологічний потяг до психоактивної речовини. До «слабких ланок» особистості відносять такі порушення: нерішучість, інтровертованість, низьку переносність негативних емоцій, безвідповідальність, повстання проти загальноприйнятих соціальних цінностей, надмірна цікавість (В. Лисовський, Е. Колесникова), емоційну незрілість, неповноцінну психосексуальну орієнтацію, садистські та мазохістські прояви, агресивність і нетерпимість, слабкі адаптаційні здібності, схильність до регресивної поведінки, нездатність до міжособистісного спілкування з партнером, труднощі в регуляції власної поведінки, трудності прогнозування наслідків власних дій, порушення мотиваційно-потребової сфери. Звісно, що не усі підлітки і юнаки починають вживати ПАР, вважається що існують особистісні особливості, які складають так званий «антинаркотичний бар'єр» (A.W. Stasy, M.B. Newcomb, P.M. Bentler).

Метою дослідження було емпіричне вивчення особливостей особистостей різного віку, що мають ризик наркотизації або є резистентними до вживання ПАР.

Для розв'язання поставленої мети було використано такий комплекс методів: теоретико-методологічний аналіз психологічних першоджерел з досліджуваної проблеми, узагальнення та порівняння теоретичних даних, класифікація та систематизація матеріалу; методи психологічної діагностики та методи математичної обробки даних (описова статистика, кластерний аналіз, однофакторний дисперсійний аналіз (ANOVA), U-критерій Манна-Уітні). Метод психологічної діагностики містив: експрес-методику раннього виявлення схильності до наркоманії («Кассандра»), модифікований варіант методики Т. Лірі (ДМВ, Л.М. Собчик), методику «Тест сенсожиттєвих орієнтацій» (СЖО, Д.О. Леонтьєв), «Графічний тест Коттла» за Р.Б. Браун та Р. Херінг.

За результатами кластерного аналізу в групі досліджуваних підлітків був проведений розподіл підлітків на 2 групи. Далі за допомогою факторного аналізу встановлено 2 фактори, що описують підлітків кожної групи. Так, у першій групі:

1 фактор «Впевнений, цілеспрямований без ризику наркотизації» (особистісні передумови (-,821), Незалежний - домінуючий $(, 771)$, цілі $(, 677))$.

2 фактор «Контролюють життя, що наповнено сенсом» (Локус контролю - Я $(, 853)$, Процес $(, 730)$, Співпрацюючий - конвенційний $(, 644))$.

У підлітків другої групи:

1 фактор «Допускають вживання наркотичних речовин з імовірністю зриву» (Ставлення до наркотиків $(, 866)$, Владний - лідируючий $(, 850)$, Ризик нервово-психічного зриву $(, 750)$, Обізнаність $(, 750))$.

2 фактор «Доброзичливий, незадоволений» (Співпрацюючий -конвенційний $(, 801)$, Результат $(, 738)$, Психосоціальні передумови $(, 722))$.

Враховуючи все вищезазначене, групи підлітків отримали назву:

Перша - Без Ризику Наркотизації, упевнені, цілеспрямовані (умовне позначення БРНп), друга - Допускають Вживання Наркотичних речовин з імовірністю зриву (умовні позначення група ДВНп).

За допомогою U-критерію Манна-Уітні встановили розбіжності між цими групами БРНп і ДВНп за наступними змінними: «Обізнаність», «Владний - лідируючий», «Незалежний - домінуючий», «Прямолінійний агресивний», «Недовірливий - скептичний», «Відповідальний - великодушний», «Локус контролю - життя». За змінною «Обізнаність» у групі ДВНп 63,6\% і 27,3\% підлітків з рівнями вище-середнього і високого, в групі БРНп відповідно 48,1\% і 3,7\%, але у 7,4\% існує надвисокий рівень. За змінною «Владний - лідируючий», в групі ДВНп низький рівень у 100\%, а в групі БРНп 37\% підлітків з низьким рівнем і 59,3\% з вищим за середній. За змінною «Незалежний - домінуючий» в групі ДВНп низький рівень у 100\%, а в групі БРНп 40,7\% підлітків мають вище середнього, за змінною «Прямолінійний - агресивний» в групі ДВНп низький рівень у $100 \%$, а в групі БРНп у 48,1\% підлітків рівень вище середнього, за змінною «Недовірливий - скептичний» в групі ДВНп низький рівень у $100 \%$, а в групі БРНп у 29,6\% підлітків вище середнього; за змінною «Відповідальний - великодушний» в групі ДВНп низький рівень у $81,8 \%$ і у $18,2 \%$ вище середнього, а в групі БРНп 40,7\% підлітків мають низький рівень, 33,3\% вище середнього і 25,9\% висо- 
кий; за шкалою «Локус контролю - життя» в групі ДВНп низький рівень у $54,5 \%$, середній у $31,8 \%$ і високий у $13,6 \%$, а в групі БРНп відповідно 22,2\%, 51,9\%, 25,9\%. Таким чином, підлітки групі БРНп відрізняються від підлітків групи ДВНп вираженими особистісними властивостями середнього рівня у схильності до конфліктної поведінки, незалежності думок, прагненням до лідерства і домінування, з бажанням допомагати оточенню і з наявністю переконання, що вони контролюють життя, в них в меншому ступені виражена обізнаність щодо наркотичних речовин.

У групі юнаків за допомогою кластерного аналізу було виділено також дві групи. За допомогою факторного аналізу встановлено 3 фактори, що описують юнаків кожної групи. Так, у першій групі:

1 фактор «Ризик наркотизації при неусвідомленому сенсі життя» (Особистісні передумови (-,970), Цілі (,943), Локус контролю - Я (,943), Ризик нервово-психічного зриву $(-, 844)$, Локус контролю - життя $(, 837)$, Результат (,821),

2 фактор «Реалістичні в теперішньому» (Недовірливий - скептичний $(, 852)$, Процес $(-, 844)$,

3 фактор «Знання та оточення» (Обізнаність (,900), Психосоціальні передумови (,797), Ставлення до наркотиків $(, 757)$, Незалежний домінуючий (,791)).

У юнаків другої групи:

1 фактор «Усвідомлюване життя» (Результат (,934), Локус контролю - Я $(, 901)$, Цілі (, 866), Процес (,778), Локус контролю - життя $(, 787))$.

2 фактор «Доброзичливість» (прямолінійний - агресивний $(-, 830)$ Незалежний - домінуючий $(-, 803)$, Співпрацюючий - конвенційний $(, 732))$.

3 фактор «Зв'язаність часових зон» (Зв'язаність часових зон $(, 733)$, Залежний - слухняний $(-, 623)$, Недовірливий - скептичний $(, 602))$.

Враховуючи все вищезазначене, групи отримали назву:

Перша група отримала назву - Ризик Наркотизації при усвідомленому сенсі життя, знаннях та оточенні (РНю); друга - Усвідомлені Сенсом життя, з пов'язаними минулим, теперішнім і майбутнім (УСю).

За допомогою U-критерію Манна-Уітні ми встановили розбіжності між цими 2 групами за наступними змінними: «Обізнаність», «Прямолінійний - агресивний», «Співпрацюючий - конвенційний», «Відповідальний - великодушний» встановлені розбіжності. За змінною «Обізнаність» у групі РНю 45\% і 25\% юнаків з рівнями вище середнього і високого, в групі УСю відповідно 20\% і 15\%. За змінною «Прямолінійний - агресивний», в групі РНЮ низький рівень у $100 \%$, а в групі УСю у $45 \%$ юна- ків низький рівень і 55\% середній. За змінною «Співпрацюючий - конвенційний» в групі РНю низький рівень у $100 \%$, а в групі УСю у 55\% юнаків низький рівень, у $35 \%$ середній і у $10 \%$ високий. За змінною «Відповідальний - великодушний» в групі РНю низький рівень у $100 \%$, а в групі УСю $35 \%, 50 \%$ і 15\% мають відповідно низький, середній і високий. Таким чином, у групі Усю, на відміну від групи РНю, вираженими є особистісні властивості середнього рівня з низьким рівнем обізнаності про наркотичні речовини.

Таким чином, встановлено групи уваги / групи ризику у підлітків і юнаків: у підлітків це група, що «допускають вживання наркотичних речовин з імовірністю психічного зриву», а у юнаків - група, що має «ризик наркотизації при усвідомленому сенсі життя, знаннях та оточенні». Порівняння цих груп за U-критерієм Манна-Уітні представлено в таблиці 1.

Таблиця 1

Порівняння груп уваги підлітків і юнаків за U-критерієм Манна-Уітні

\begin{tabular}{|l|c|}
\hline \multirow{2}{*}{ Змінні } & \multicolumn{2}{|c|}{ Групи уваги } \\
\cline { 2 - 2 } & Підлітки \\
\hline Обізнаність &, 002 \\
\hline Особистісні передумови &, 039 \\
\hline Владний - лідируючий &, 000 \\
\hline Недовірливий - скептичний &, 006 \\
\hline $\begin{array}{l}\text { Співпрацюючий - конвен- } \\
\text { ційний }\end{array}$ &, 006 \\
\hline $\begin{array}{l}\text { Відповідальний - велико- } \\
\text { душний }\end{array}$ &, 048 \\
\hline Процес &, 039 \\
\hline Цілі &, 002 \\
\hline Локус контролю - &, 007 \\
\hline
\end{tabular}

Аналіз таблиці 1 показує, що група уваги юнаків відрізняються від групи уваги підлітків вираженістю наступних стилів міжособистісної поведінки: владний - лідируючий (вище середнього рівня) $(p<, 000)$; недовірливий - скептичний $(p<, 006)$. Тобто юнаки групи уваги не визнають критику, переоцінюють власні можливості, можуть бути недовірливими до оточення за реалістичності суджень. Вони володіють більш глибокими знаннями про наркотичні речовини, способи їх застосування, мають більшу вираженість ризику наркотизації $(p<, 000)$; вони $€$ більш цілеспрямованими ( $p<, 002)$; життя сприймають як емоційно насичене і наповнене сенсом, уявляють себе як сильну особистість, що має свободу вибору $(p<, 007)$. В юнаків групи уваги в меншому ступені, ніж у підлітків, виражені якості типів співпрацюючий - конвенційний та відповідальний - великодушний, тобто їм властиве почуття відповідальності і вони в міру доброзичливі. 
Порівняння груп юнаків і підлітків, що не мають ризику наркотизації, показало, що вони відрізняються за U-критерієм Манна-Уітні тільки за змінними: Обізнаність $(p<, 048)$ та Покірний - сором'язливий $(p<, 035)$. У юнаків цієї групи більше знань про наркотичні речовини та вони є більш скромними, можуть брати на себе обов'язки інших.

Висновки 3 проведеного дослідження. Таким чином, ризик наркотизації $є$ імовірним у підлітків і юнаків. Підлітки, що мають ризик наркотизації, обізнані щодо наркотиків на вище за середній рівень, у них низький рівень вираженості рис типів «Владний - лідируючий», «Незалежний - домінуючий», «Прямолінійний - агресивний», «Недовірливий - скептичний», «Відповідальний - великодушний», їм притаманні низький і середній рівень за субшкалою «Локус контролю - життя». Юнаки, що мають ризик наркотизації, є більш владними, недовірливими, цілеспрямованими, 3 наповненим сенсом життям і свободою вибору, у більшому ступені $€$ обізнаними про наркотичні речовини. Попри наявність ризику наркотизації, підлітки і юнаки відрізняються за обізнаністю, особистісними передумовами, стилями міжособистісної поведінки, сенсожиттєвими орієнтаціями.

\section{ЛITEPATУРA:}

1. Битенский В.С., Херсонский Б.Г., Дворяк С.В., Глушков В.А. Наркомании у подростков. Киев : Здоровье, 1989.

2. Змановская Е.В. Девиантология: (Психология отклоняющегося поведения) : Учеб. Пособие для студ. Высш. Учеб. Заведений. Москва : Издательский центр «Академия», 2003. 288 с.

3. Литвинчук Л.М. Основні підходи до вивчення проблеми наркотичної залежності. URL: http://www.appsychology.org.ua/data/jrn/v5/i16/14.pdf.

4. Наркология / [Фридман Л.С., Флеминг Н.Ф., Робертс Д.Х., Хайман С.Е.] / Пер. С англ. Санкт-Петербург : Невский Диалект, 2000. 320 с.

5. Bandura A. Social Foundations of Thought and Action: A Social Cognitive Theory. Englewood Cliffs, NJ : Prentice Hall; 1986.

6. Boden J.M. Alcohol misuse and violent behavior: Findings from a 30-year longitudinal study / Boden J.M., Fergusson D.M., Horwood L.J. Drug and Alcohol Dependence. 2012. Vol. 122, № 1-2. P. 135-141.

7. Brain in Progress: Why Teens Can't Always Resist Temptation, National Institute on Drug Abuse (NIDA), 2015 January. URL: http://www.drugabuse.gov/aboutnida/noras-blog/2015/01/brain-in-progress-why-teenscant-always-resist-temptation.

8. Prevalence and determinants of resistance to use drugs among adolescents who had an opportunity to use drugs. URL: https://www.ncbi.nlm.nih.gov/pmc/ articles/PMC4361287/\#FN4. 